\title{
Physics Learning Instruction Based on the Conceptual Change Model for Senior High Schools
}

\author{
Aminatul Munawaroh ${ }^{1, *}$ Insih Wilujeng ${ }^{2,}$ Zul Hidayatullah $^{3}$ \\ ${ }^{1,3}$ Master of Physics Education, Faculty of Mathematics and Natural Sciences, Universitas Negeri Yogyakarta, \\ Indonesia \\ ${ }^{2}$ Department of Natural Science Education, Faculty of Mathematics and Natural Sciences, Universitas Negeri \\ Yogyakarta, Indonesia \\ *Corresponding author. Email: aminatulmunawaroh0996@gmail.com
}

\begin{abstract}
This research developed a learning instruction in physics based on the conceptual change model (CCM). The development model uses a procedure from R\&D. This development consisted of four steps that were define, design, develop, and disseminate. Development of physics learning instruction that was developed consisted of syllabus, lesson plan, worksheet earning materials. This research aimed to know the validity of learning instruction. Based on the result, learning instruction based on conceptual change model was valid with good categorized and could be used for the next step. The developed learning instruction was also practice based on the student's response analysis result.
\end{abstract}

Keywords: Learning instruction, Conceptual change model

\section{INTRODUCTION}

Physics is science which studies a lot of natural phenomena and their symptoms. Physics is a science studying the interaction between energy and material as the basis of natural sciences. In physics learning, students are expected to master physics concepts theoretically and use the scientific method to prove physics concepts obtained from the theory [1]. Physics learning has a purpose that students can have physics problem-solving ability, not just to memorize [2]. Physics on senior high school level has several purposes, among them : 1. Developing reasoning ability in inductive and deductive analysis thinking by using physics concepts and principal to explain various natural events and solve problems both qualitatively and quantitatively; 2. Mastering physics concept and principal and having the skill to develop knowledge and self-confidence as a provision to continue a higher education level, and developing science and technology [3].

Based on the purpose above, conceptual understanding is essential for students as a basis to continue higher education level and as a provision to apply to daily life or to solve problems in daily live. The learning done is mostly less attention to students' early concepts so that students just know the idea without understanding the meaning because it does not relate to the early learning and event related to daily life [4]. The learning will be more meaningful and effective if the learning activity is not only for getting knowledge but also using the knowledge gained to solve problems being studied [5]. The readiness of the teacher in making lesson plans is also related to the quality of the learning process carried out. Selection of the right method, availability of media, assessment that includes attitudes, knowledge and skills, and students can work together to create meaningful learning that is guided by the curriculum used. Implementation of the 2013 Curriculum directs teachers to develop student-centered learning. Student-centered learning will provide a role for students to carry out their own construction and knowledge search [6]. Conceptual change model learning make students better understand the concept in depth in order to be of benefit to his life. This model demands teachers more of a role as a director formation of scientific concepts, so that teachers more of a role as a facilitator, negotiator and confrontator. The goal is to guide students towards current scientific views and link to his cognitive schema. Students basically already have an initial concept because 
learning does not only start from school but also since interacting with the environment, so that when learning at school students already have thoughts or ideas that are formed as topics. Some of these ideas or thoughts are in line with scientific concepts but some of the ideas are also different [7]. One alternative in solving physics problems is by applying a conceptual change learning model. The conceptual change learning model makes students the center of learners so that they can make learning meaningful. The conceptual change learning model is used with the aim that students can develop their thinking or change their views which are considered not in accordance with the views of scientists until they are in accordance with the views of scientists [8]. Students get the opportunity to express the initial concepts they have and then be directly involved in real events according to the concepts being discussed. The conceptual change learning model is one of the learning models based on constructivism [9]. Constructivism places more emphasis on learning situations and views learning as contextual [10]. Misconceptions are ideas that arise in students' minds that are personal and generally the idea is non-existent scientific. Misconceptions can also be obtained from different experiences and sources of information that are not accurate. This is a bad foundation for students in constructing knowledge [11]. Physics learning should be focused on replacement efforts misconceptions experienced students with scientific concepts. This can be done through confrontational learning in a way confront the misconceptions experienced by students with the concept of the experts at the time do social interaction in class, because confrontation and replacement of misconceptions inseparable [12]. The conceptual change model states that students who come to class will accompanied by misconceptions regarding natural phenomena and the misconceptions must be expressed and confronted with explanation or demonstration of conflicting examples and corrections by providing a concept that is more general to be accepted and understood [13].

Piaget said that if constructive theory is used to build one's knowledge, to form a higher balance of knowledge, needed, assimilation is which is an effective problem-solving ability between old theory and new reality [14]. Knowledge of students who are constructed it is not impossible that errors occur in construction, the result of construction is called preconception [15]. Learning that uses a constructivist view pays close attention to the initial conception and the role of students in the learning process so as to create a student-centered learning atmosphere.
Teachers are expected to create a learning atmosphere by seeing students' initial conceptions as information for further learning and improving it by convincing students of new concepts of scientists [16]. The use of conceptual change models provides opportunities for students to exchange ideas through discussions and presentations. Students find their views wrong and sometimes contrary to scientific views. This often results in dissatisfaction with old views and learners looking for new ways that are acceptable, reasonable and understandable [17]. The steps of the conceptual change learning model are presented in Figure 1.

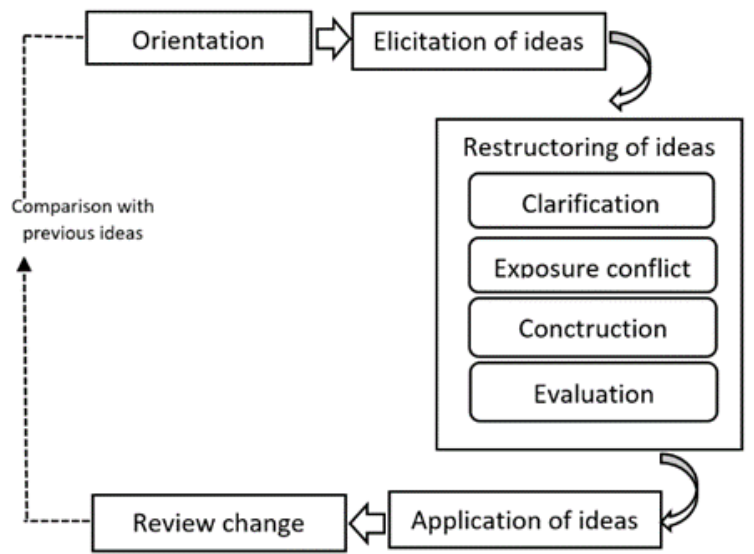

Figure 1. The steps of the conceptual change learning model.

The conceptual change learning model has the following steps: 1. Review of conceptual and intellectual problems; 2. Confrontation of misconceptions related to the problems; 3 . Confrontation of denial with strategies of demonstrations, analogies or examples; 4. Confrontation of scientific proof of concepts and principles; 5. Confrontation of material and contextual examples; 6. Confrontation of questions attempts to broaden the understanding as well as its meaningful application [18] [19]. Conceptual change learning models make students better able to understand concepts in depth so that they can be useful for their lives. This model requires the teacher to be the guide for the formation of scientific concepts, so that they can act more as facilitators.

\section{METHOD}

The research method used was Research and Development (R\&D) with the 4D model developed consisting of four stages: defining stage, designing stage, developing stage, and disseminating stage [20] 


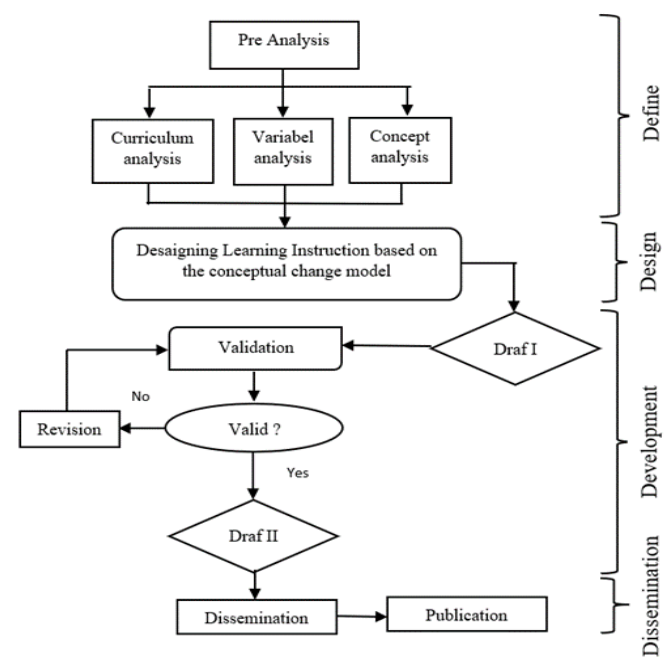

Figure 2 4D model

This research developed a learning instructions in physics based on the conceptual change model. The product (learning instruction based $\mathrm{CCM}$ ) will be validated by expert or validator from physics education. Each stage of this research consists by some stages. The defining stage consists of curriculum analysis, concept analysis, and student analysis. The designing stage is a stage of designing learning instruction includes syllabus, lesson plan, worksheet, learning material. The validation score will be analyzed by using the form of an equation [21].

$$
\mathrm{SS}=\frac{\overline{\mathrm{SS}}}{\mathrm{S}_{\mathrm{m}}}
$$

SS is validity value of the learning instruction, $\overline{\mathrm{SS}}$ is the sum of the average score of indicator of the validity, $S_{m}$ is the sum of sub indicator.

Table 1: Instrument feasibility criteria (learning media)

\begin{tabular}{|l|l|l|}
\hline Range & $\begin{array}{l}\text { Assessment } \\
\text { Criteria }\end{array}$ & Notes \\
\hline $3.26-4.00$ & Strongly valid & $\begin{array}{l}\text { Can be used with } \\
\text { no revision }\end{array}$ \\
\hline $2.51-3.25$ & Valid & $\begin{array}{l}\text { Can be used with } \\
\text { less revision }\end{array}$ \\
\hline $1.76-2.50$ & Invalid & $\begin{array}{l}\text { Can not be used } \\
\text { because it needs } \\
\text { revision }\end{array}$ \\
\hline $1.00-1.75$ & $\begin{array}{l}\text { Strongly } \\
\text { Invalid }\end{array}$ & Cannot be used \\
\hline
\end{tabular}

To declare that the learning media arranged is valid or not is by making an interpretation of expert's assessment criteria based on Table 1 [22]:

\section{RESULT}

Based on the R\&D procedure, this development research consisted of the defining stage, designing stage, and developing stage. As for the results of each stage were as follows [23][24]:

\subsection{Defining Stage (Define)}

On the defining stage, an analysis of curriculum, student, and the concept was done. The field survey was in the form of analysis of teacher, student, and curriculum that has been set in SMA Negeri 1 Ngaglik. The study materials developed were Basic Competency 3.10, namely "Applying the concepts of momentum and impulse, as well as the law of conservation of momentum in everyday life" and 4.10, namely "Presenting the results of testing the application of the law of conservation of momentum". The product of this research based on conceptual change model. The analysis result of the learning need was learning instruction consisting of syllabus, lesson plan, worksheet, learning material according to curriculum 2013. The learning instruction could be used by teachers to do Physics learning according to the demand of curriculum 2013. The analysis result of students' needs was concluded that it was needed learning that could help students to understand the material. The learning instruction should have optimized the learning process toward the conceptual change model so that students' thinking skills could increase and the learning became meaningful.

\subsection{Designing Stage (Design)}

\subsubsection{Syllabus Design}

The syllabus header contained subject identity covers: education units, class, semester, program/ expertise program, subject or lesson theme, and the number of meetings. Next, the syllabus matrix consists of basic competence, learning material, character education values, learning activity, an indicator of competence achievement, assessment, time allocation, and learning resources.

\subsubsection{Lesson Plan Design}

The learning instruction that developed in this research followed the conceptual change model syntax among others: a) As an early conception exploration, teachers presented problems by demonstrating or showing a simulation related to the material momentum and impuls; b) Asking 
several questions causing learners to experience the accommodation process on the demonstration been done then considering learners' answer to find out learners' preconception about the presented problem and giving questions to provoke learners' confidence about the preconception owned; c) Delivering principal material that would be studied by showing an animation or mentioning facts related to the material being discussed; d) Giving essay questions to find out learners' critical thinking skills as an evaluation of sub material using new accepted concepts; e) conducting a reflection about the material.

\subsubsection{Worksheet Design}

Worksheet design was adjusted to curriculum 2013, consisting of components including: worksheet, answer sheet, and assessment. The next worksheet format in the worksheet was, among others: the student's name, class, subject, learning purpose, activity steps, then completed with an answer sheet as well as an assessment sheet. The developed worksheet had a characteristic according to the conceptual change model. Figure 3 shows some parts of worksheet based on the conceptual learning model.

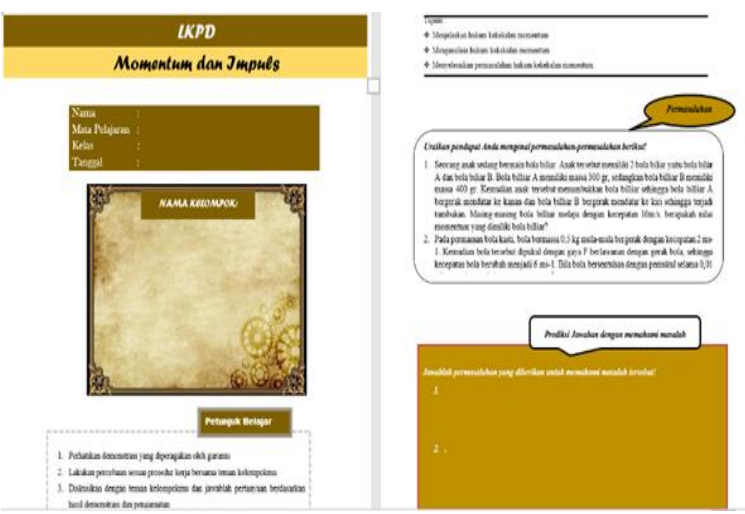

Figure 3. The illustration of worksheet based on the conceptual change model

\subsubsection{Learning Material Design}

Learning material design was adjusted to the learning model, learning purpose, and students' thinking level. Figure 4 shows some parts of learning material based on the conceptual learning model.
Momentum dan Impuls

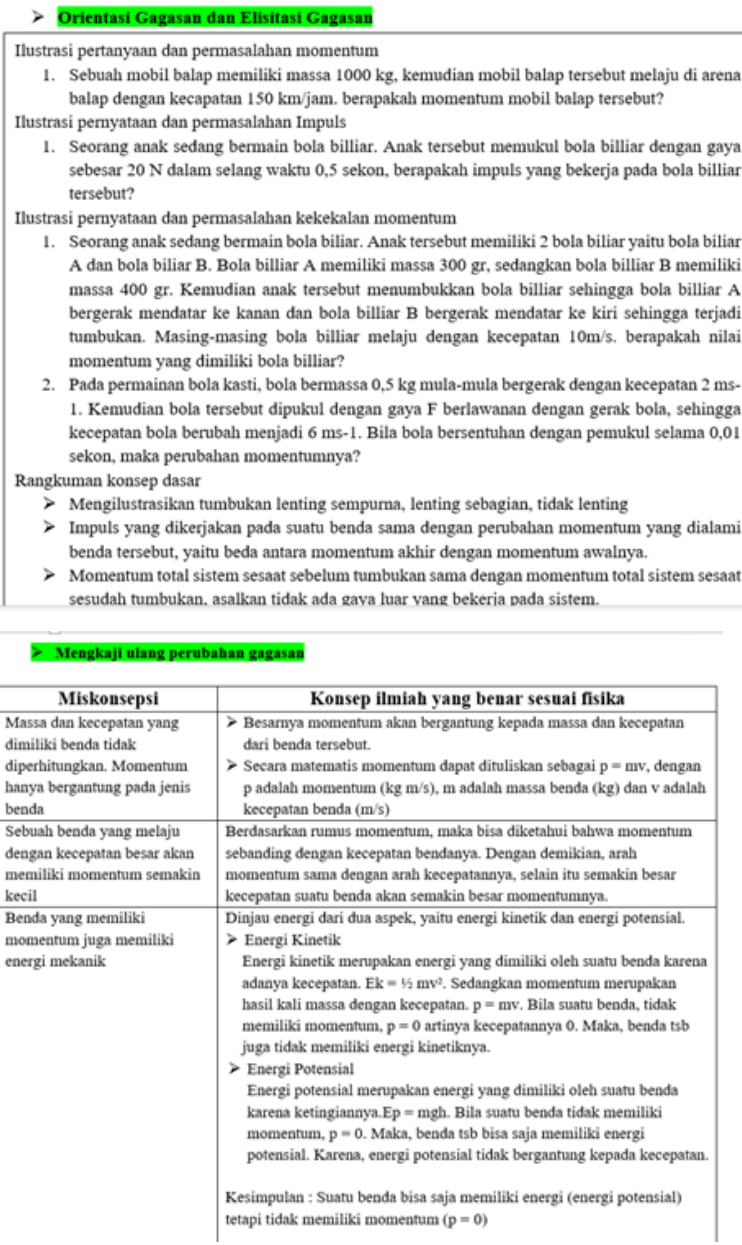

Figure 4. The illustration of learning material based on the conceptual change model

The product was developed following the design explained above. Learning instruction based on the conceptual change model that had been developed then validated by experts.

\subsection{Expert Validation Results}

Expert validation assessment results on the learning media product are shown in Table 2 as follows: 
Table 2. Validation results

\begin{tabular}{|l|l|l|l|}
\hline No & \multicolumn{1}{|c|}{ Media } & Average & Criteria \\
\hline 1 & Syllabus & 3.82 & Strongly valid \\
\hline 2 & Lesson Plan & 3.76 & Strongly valid \\
\hline 3 & Worksheet & 4 & Strongly valid \\
\hline 4 & $\begin{array}{l}\text { Learning } \\
\text { material }\end{array}$ & 3.65 & Storngly valid \\
\hline
\end{tabular}

Table 2 shows that the average result of learning media aspect fulfills strongly valid criteria so that it can be used in the learning process. There was no revision of learning media draft III after field testing, and the next was obtained physics learning media of the conceptual change model on the material that was ready to be disseminated. In the disseminating stage, the disseminate was done after obtaining a product in the form of valid physics learning media based on the conceptual change model to increase students learning activity. Product dissemination was in the form of physics learning instruction based on the conceptual change model conducted on Senior High School Physics teacher who was teaching Class X MIPA students of SMAN 1 Ngaglik.

\subsection{Learners' Response}

Assessment results of learner's response to the product are shown in Table 3 as follows:

Table 3. Learners' response results on the learning media

\begin{tabular}{|l|l|l|l|}
\hline No & $\begin{array}{l}\text { Assessment } \\
\text { Aspect }\end{array}$ & Average & Criteria \\
\hline 1 & $\begin{array}{l}\text { Content and } \\
\text { learning purpose }\end{array}$ & 3.33 & Verry Good \\
\hline 2 & $\begin{array}{l}\text { Learning material } \\
\text { selection }\end{array}$ & 3.48 & Verry Good \\
\hline 3 & Technical & 3.71 & Verry Good \\
\hline 4 & Language used & 3.35 & Verry Good \\
\hline \multicolumn{2}{|l|}{ Average } & 3.46 & Verry Good \\
\hline
\end{tabular}

Based on Table 3, it is known the content and learning purpose aspect has an average score of 3.33 with verry good criteria. The learning material selection aspect has an average score of 3.48 with verry good criteria. The technical aspect has an average score of 3.71 with verry good criteria, and the Language aspect used has an average score of 3.35 with very good criteria. Table 4 is known that the average score of four aspects of learners' response assessment is 3.46 , so that it is included in the "very good" category.

\section{CONCLUSION}

Physics learning media based on the conceptual learning model impulse and momentum material in class X MIPA of SMAN 1 Ngaglik developed with curriculum 2013 characteristic is based on the learning component with the conceptual change model. The assessment done by experts shows that the learning media developed is declared feasible to use for learnings. The assessment done by learners as the respondent also shows the feasibility of learning media developed with verry good criteria. Thus, it can be concluded that the development of physics learning media based on the conceptual change model is feasible to use in physics learning.

\section{REFERENCES}

[1] Hermansyah, L. Gunawan, Herayanti, Pengaruh Penggunaan Laboratorium Virtual Terhadap Penguasaan Konsep dan Kemampuan Berpikir Kreatif Siswa pada Materi Getaran dan Gelomban, Jurnal Pendidikan Fisika dan Teknologi (1) (2015) 97-102. DOI: https://dx.doi.org/10.29303/jpft.v1i2.242

[2] I. N. Wals, R. G. Howard, B. Bowe, Phenomenographic Study Of Students' Problem Solving Approaches In Physics, Physical Review Physics Education Research (3) (2007) 1-12. DOI:

https://doi.org/10.1103/PhysRevSTPER.3.0201 $\underline{08}$

[3] Departement pendidikan nasional, Kurikulum Tingkat Satuan Pendidikan Sekolah Menengah Atas/Madrasah Aliyah, Depdiknas, 2006.

[4] R. Tuqalby, Sutrio, Gunawan, Pengaruh Strategi Konflik Kognitif Terhadap Penguasaan Konsep Pada Materi Fluida Siswa SMAN 3 Mataram Tahun Ajaran 2016/2017, Jurnal Pendidikan Fisika dan Teknologi (3) (2017) 8-13. DOI: https://dx.doi.org/10.29303/jpft.v3i1.317

[5] M. Wena, Strategi Pembelajaran Inovatif Kontemporer, PT. Bumi Aksara, 2014.

[6] D. Pebriyanti, H. Sahidu, Sutrio, Efektifitas Model Pembelajaran Perubahan Konseptual untuk Mengatasi Miskonsepsi Fisika pada Siswa Kelas X SMAN 1 Praya Barat Tahun Pelajaran 2012/2013, Jurnal Pendidikan Fisika dan 
Teknologi (1) (2015) 92-96. DOI: http://dx.doi.org/10.29303/jpft.v1i2.241

[7] U. A. Denis, J. J. Williams, A. Y. Dunnamah, D. P. Tumba, Conceptual Change Theory As A Teaching Strategy In Environmental Education, European Scientific Journal (11) (2015) 395-408.

[8] P. I. W. Eka, I W. Sadia, I. W. Suastra, Pengaruh Model Pembelajaran Perubahan Konseptual terhadap Pemahaman Konsep Siswa Ditinjau dari Gaya Kognitif, E-Journal Program Pascasarjana Universitas Pendidikan Ganesha Program Studi IPA (4) (2014) 1-12.

[9] Hamdani, Strategi Belajar Mengajar, CV. Pustaka Setia, 2011.

[10] M. Makhrus, Validitas Model Pembelajaran Conceptual Change Model With Cognitive Conflict Approach, Jurnal Ilmiah Profesi Pendidikan (3) (2018) 62-66. DOI: https://dx.doi.org/10.29303/jipp.v3i1.54

[11] S. N. W. Silung, S. Kusairi, S. Zulaikha, Diagnosis Miskonsepsi Siswa SMA di Kota Malang pada Konsep Suhu dan Kalor Menggunakan Three Tier Test, Jurnal Pendidikan Fisika dan Teknologi 2(3) (2016) 95105. DOI: http://dx.doi.org/10.29303/jpft.v2i3.295

[12] J. P. Smith, A. A. diSessa, J. Roschelle, Misconception reconceived: A Constructivist Analysis of Knowledge in Transition, The Journal of the Learning Science (3) (1994) 115163.

DOI: https://doi.org/10.1207/s15327809j1s0302_1

[13] M. Cakir, Constructivist Approaches to Learning In Science And Their Implications for Science Pedagogy: A literature review International, Journal of Environmental \& Science Education 3(4) (2008) 193-206.

[14] P. Suparno, Miskonsepsi Perubahan Konsep dalam Pendidikan Fisika, Gramedia Widiasarana Indonesia, 2013.

[15] M. M. A. Sarar, Conceptual Change Theory As A Teaching Strategy In Environmental Education, European Scientific Journal (10) (2014) 191-203.

[16] B. Tlala, I. ibirige, J. Osodo, Investigating Grade 10 Learners' Achievements In Photosynthesis Using Conceptual Change Model, Journal of Baltic Science Education (13) (2014) 155-164.
DOI:

https://doi.org/10.19044/esj.2014.v10n22p\%25p

[17] R. W. Dahar, Teori-Teori Belajar, Erlangga, 1996.

[18] R. Diani, Pengembangan Perangkat Pembelajaran Fisika Berbasis Pendidikan Karakter dengan Model Problem Based Instruction, Jurnal Ilmiah Fisika Al-Birun (4) (2015) 241-254. DOI: https://doi.org/10.24042/jpifalbiruni.v4i2.96

[19] B. C. Madu, E. Orji, Effects of Cognitive Conflict Instructional Strategy on Students' Conceptual Change in Temperature and Heat, Sage Journals, (5) (2015).

DOI:

Https://doi.Org/10.1177/2158244015594662

[19] Istiyono, E. Pengembangan Instrumen Penilaian dan Analisis Hasil Belajar Fisika, UNY Press, 2017.

[20] D. Hamka, N. Effendi, Pengembangan Media Pembelajaran Blended Learning Berbasis Edmodo pada Mata Kuliah Fisika Dasar di Program Studi Pendidikan IPA, Journal of Natural Science and Integration (2) (2019) 1-19. DOI: http://dx.doi.org/10.24014/jnsi.v2i1.7111

[21] R. Tesi Muskania, I. Wilujeng, Pengembangan Perangkat Pembelajaran Project-Based Learning untuk Membekali Foundational Knowledge Dan Meningkatkan Scientific Literacy, Cakrawala Pendidikan Jurnal Ilmiah Pendidikan (36) (2017) 34-43.

DOI: https://doi.org/10.21831/cp.v36i1.8830

[22] Sugiyono, Metode Penelitian Pendidikan: Pendekatan Kuantitatif, Kualitatif, dan R\&D, Alfabeta, 2017.

[23] P. Setyosari, Metode Penelitian Pendidikan dan Pengembangan, Kencana, 2015.

[24] S. D. Puti, Pengembangan Perangkat Pembelajaran Fisika Berbasis Keterampilan Berpikir Kritis dalam Problem-Based Learning, Jurnal Ilmiah Pendidikan Fisika Al-Biruni (6) (2017) 125-135. DOI: Https://doi.org/10.24042/jpifalbiruni.v6i1.648 